\title{
A Model of Speaking Teaching Materials for Primary English Teachers' Candidates Based on Contextual Approach
}

\author{
Dayu Retno Puspita ${ }^{1}$, Asih Rosnaningsih ${ }^{2}$ \\ ${ }^{1}$ Universitas Muhammadiyah Tangerang \\ email: dayuretnopuspita@gmail.com \\ ${ }^{2}$ Universitas Muhammadiyah Tangerang \\ email: asihrosna@gmail.com
}

\begin{abstract}
The purpose of this research is to develop teaching materials in English speaking skills that are suitable for the needs of primary English teachers' candidates in the Teacher Training and Education Faculty of Muhammadiyah University of Tangerang. The research is designed with a research and development study or R and D cycle consisting of seven steps: literature study, needs analysis, syllabus analysis, teaching material development, product validation, product testing and final product. Data collection techniques used observation, interview, questionnaire and product tests. The findings of the study reveal that 12 chapters of speaking teaching material was chosen for Primary English teachers' candidates based on contextual approach, namely: greeting and introducing, counting numbers, talking about family, describing objects, talking about houses, school and class environment, telling time and talking about daily activity, talking about feeling and health issues, shopping time, asking and giving directions, talking about plans and telling past experiences. The results of the effectiveness test show that speaking teaching materials are stated to be good. These findings call for lecturers to apply the teaching material developed in the learning process as a main reference or as a supplementary material so that it can make learning material more interesting, innovative, and effective.
\end{abstract}

Keywords: Teaching Materials, Speaking Skill, and Primary English Teachers' Candidates.

\section{INTRODUCTION}

Elementary School Teacher Education Study Program Faculty of Teacher Training Education University of Muhammadiyah Tangerang is a faculty that organizes education and learning in the field of primary school education in a professional manner with the aim of producing undergraduate elementary school teacher education who have personal, pedagogical, professional competencies in the academic field and can develop science and learning innovations in the elementary school field (Pedoman Akademik UMT, 2015). Primary School Teacher Education Muhammadiyah University Tangerang as an educational institution that prepares prospective professional teachers at the elementary school level in the future must be able to 
answer the challenge of being able to develop all the potential of students including the potential of good and quality English.

One of the qualifications of undergraduates according to the Indonesian National Qualification Framework (KKNI) based on Presidential Regulation No. 8 of 2012 is able to apply their fields of expertise and utilize science, technology, and/or art in their fields in problem solving and able to adapt to the situation at hand. Referring it, Primary School Teacher Education students are equipped with English courses as a provision that will be taught in elementary schools. This program study provides a distribution of English courses for three semesters, namely: semester 1 of English courses, semester 3 of English for Math and Science and semester 5 of English for Children (Pedoman Akademik UMT, 2015). In accordance with the formulation of achievements in English courses in Primary School Teacher Education, speaking skills is one of the skills students must possess. The importance of students mastering the ability to communicate in spoken English.

Based on observations of teaching materials and interviews conducted by researchers to several English lecturers in Primary School Teacher Education, there are several facts about teaching materials that have been used. first, the contents of teaching materials are still theoretical that tends to contain theories of learning English and have not provided students the opportunity to practice their speaking skills. Second, the contents are also more dominated by a collection of elementary school English vocabulary lists. The lecturer only explained the elementary school English vocabulary list by asking students to translate it. Teaching speaking is more emphasized on the language system, especially teaching vocabulary and grammar than speaking practice (Bahrani, 2012). Third, the lack of speaking teaching materials so that students can communicate and interact actively during the teaching and learning process that can increase interest and motivation to learn English. Students still have inability in vocabulary, grammar, and pronunciation is the most common difficulty when they learn English speaking skills (Quinn, 2014). Fourth, limited conversational models and exercises to develop students' English speaking skills, 5) teaching materials used tend to be written activities, lecturers are more asking students to complete conversations not to practice conversation, 6) the material used has stil taken from text books that are sometimes not contextual.

Departing from the problems above, the development of teaching materials in this research is expected to primary English teachers' candidates can have language competence and use English as a communication tool both inside and outside the classroom and not only about English but how to use English in the learning. It is also developed by using a contextual approach. Contextual material used to teach English, especially for speaking skills, is still not available at some universities. The lecturers only use existing material taken from text books that are sometimes not contextual (Andi Tenri Ampa, 2013). Therefore, it was chosen for primary English teachers' candidates where the learning characteristics of elementary school students were concrete and meaningful.

\section{Teaching materials}

Teaching material is anything that is pleased with a systematic description of the techniques and exercises used by instructors and students in the learning process (Brown, 1995; Pannen, 1996). It can include textbooks, material derived from audio and visual programs, games, or various types of activities that take place in class. The key to developing suitable material is to ensure that 
the material provided is described and organized efficiently and properly. So that teachers can teach it with time and preparation that is not too long. Moreover, Madjid (2011) state that teaching materials are all forms of materials used to assist teachers in carrying out teaching and learning activities. The material can be either written material or unwritten material. It allows students to learn a basic competency or competency coherently and systematically so that they are able to master all competencies in an integrated and integrated manner.

Tomlison (2013) classifies the types of teaching materials: 1) audio teaching materials, such as cassettes; 2) visual teaching materials, such as dictionaries, grammar books, various types of reading, workbooks, photocopied teaching materials, newspapers, photos and handwritten cards; 3 ) audio-visual teaching materials, such as videos, $\mathrm{CD}$ rooms, talks in live broadcasts, instructor instructions, food packages and student discussions; 4) teaching materials come from outside the classroom, such as talks from live broadcasts, newspapers, food packages; 5) teaching materials come from the classroom, such as instructor's instructions, discussions between students; 6) written teaching materials, such as dictionaries, grammar books, various types of readings, work books, teaching materials in the form of photocopies, newspapers, hand written cards; 7) oral teaching materials, such as talks from live broadcasts, instructor instructions, student discussions; 8) material with objects, such as tapes, CD-rooms, food packages, dictionaries, grammar books, various reading materials, work books, teaching materials in the form of photocopies, newspapers, folios and handwritten cards.

Ellington and Race (1993) classify types of teaching materials based on their shape, namely: 1) printed and duplicate teaching materials, such as handouts, student worksheets, self-study materials, materials for group learning; 2) non-projected display teaching materials, such as flipcharts, posters, models, and photographs; 3) projected display teaching materials, such as slides, filmstrips, etc.; 4) audio teaching materials, such as audiodisc, audio tapes, and radio broadcasts; 5) audio teaching materials that are connected with still visual material, such as sound slide programs, sound filmstrip programs, tape models, and realia tapes; 6) video teaching materials, such as television broadcasts, and videotape recordings; 7) computer teaching materials, such as Computer Assisted Instruction (CAI) and Computer Based Tutorial (CBT).

According to Madjid, teaching materials at least have: 1) study instructions, learning instructions function to guide training activities from the beginning to the end of the activity and conclude something as the final target of learning; 2) Competencies to be achieved, one basic competency is usually designed into several learning activities depending on the depth of the material; 3) Supporting information, is a general description of what students should do in using teaching materials. 4) Exercises, is a form of reinforcement that is obtained by students and must be given in every teaching material presented; 5) Work instructions, can be in the form of worksheets 6) Evaluation, is the final stage of learning that can measure the level of student achievement in learning (Madjid, 2011).

\section{Speaking skill}

Freeman states that the success of foreign language learning is measured by the ability to carry out conversations using the foreign language (Sad, 2008). The general speaking process consists of four stages, namely pre-speaking, while-speaking, postspeaking, and extension practice. In pre- 
speaking, students are given sufficient time to plan and the teacher provides assistance in both language and knowledge. In prespeaking, there are three ways that can be taken, namely pre-task planning, prespeaking support, and authentic input. In pretask planning students are given enough time to formulate ideas that will be conveyed in the process of speaking. In pre-speaking support, students are given assistance in the form of vocabulary and initial information related to the topic being studied. While in authentic input, students are given examples of speaking through the use of authentic media, both visual, audio, or audio visual, which can facilitate students in speaking activities. In the second stage, namely while speaking, there are several activities that can be carried out, among others, speaking tasks, fluency technique, and forming automaticity. Three types of speaking tasks that can develop fluency are information-gap, problem-solving, and social monologue. In the post-speaking stage, the level of accuracy of students in speaking is emphasized through 3 (three) activities, namely language focus, self-repair, and corrective feedback (Wang, 2014). There are five components that affect a person's general speaking skills in the process of analysis, namely comprehension, vocabulary, grammar, fluency, and pronunciation (Brown, 2001). there are three components that can be used as guidelines in evaluating students' speaking abilities, including: (1) pronunciation, (2) accuracy, (3) fluency (Spratt, et al, 2005).

\section{Contextual approach}

Contextual teaching learning (CTL) is a holistic system. It consists of interrelated parts that, when intermoven, produce an effect that exceeds what any single part could achieve. Just as the violin, cello, clanet and other instruments in an orchestra produce distinctive sounds that together generate music, so CTL's separate parts involve distinctive processes that, when used together, enable students to make connections that generate meaning. Each of these distinct elements of the CTL system contributes to helping students make sense of schoolwork. Taken together, they form a system that makes it possible for students to see meaning in, and retain, academic material (Johnson, 2002).

\section{METHOD}

This research is designed with a model development (research and development) or $\mathrm{R}$ and $\mathrm{D}$ cycle. Educational research and development (R\&D) is a process for developing and validating educational products. R\&D models (Gall, M.D; Gall, J.P., $\&$ Borg, 2003). The research is designed with a research and development study or $\mathrm{R}$ and $\mathrm{D}$ cycle consisting of ten steps: (1) needs analysis, (2) data collection, (3) product design, (4) design validation, (5) design revisions, (6) product trials in small groups, (7) product revisions, (8) product trials in large groups, (9) product revisions, (10) mass production. English lecturers and students in primary school teacher education program study, participated in this study. The modification of the Borg and Gall development model is as in Figure 1 below: 
Figure 1: Modification of the Borg and Gall Development Model in the Speaking Teaching material model

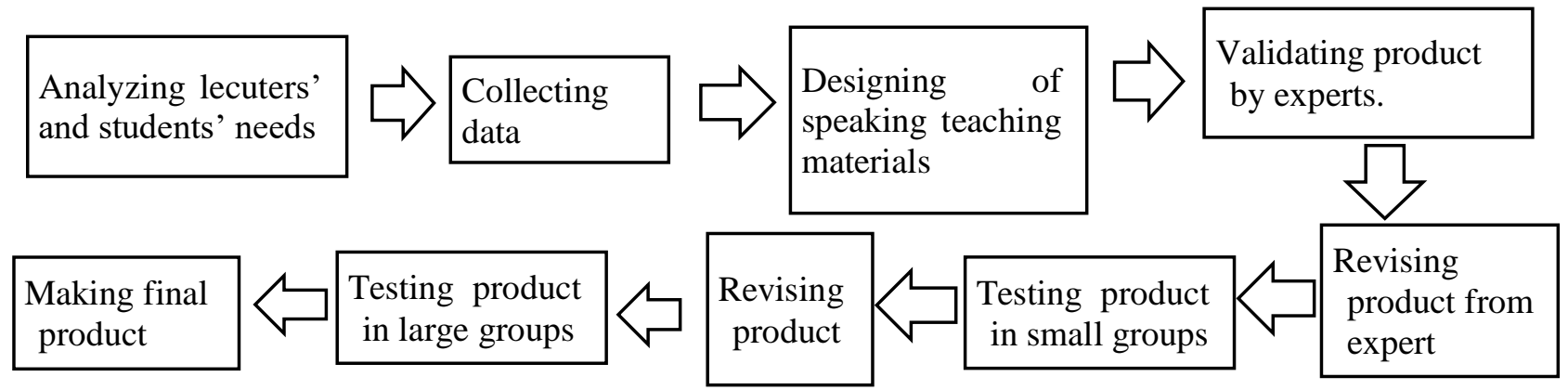

Data collection techniques used observation, interviews questionnaires, and product test. The data to be obtained in this study consists of two types, namely quantitative data and qualitative data. Quantitative data were obtained from the results of a questionnaire, expert judgment (material experts and linguists). In addition, quantitative data will also be obtained based on test instruments and observation sheets.

The data obtained in this section is the score of the respondents' answers to the items in the questionnaire and the opinions or suggestions of the respondents written in the section provided in the questionnaire distributed to respondents.

The overall data collection techniques and instruments can be seen in the following table:

Table 1. Data Collection Techniques and Research Instruments

\begin{tabular}{lll}
\hline \multicolumn{1}{c}{ Research Stages } & $\begin{array}{c}\text { Data collection } \\
\text { technique }\end{array}$ & \multicolumn{1}{c}{ Instrument } \\
\hline $\begin{array}{l}\text { 1. Making observations about the condition of existing } \\
\text { teaching materials }\end{array}$ & Observation & Observation sheet \\
\hline $\begin{array}{l}\text { 2. Identifying students needs for expected teaching } \\
\text { materials }\end{array}$ & $\begin{array}{l}\text {-Questionnaire } \\
\text {-Interview }\end{array}$ & $\begin{array}{l}\text { - Questionnaire } \\
\text { - Interview guidelines }\end{array}$ \\
\hline $\begin{array}{l}\text { 3. Measuring the level of success of students towards } \\
\text { testing teaching materials that are developed. }\end{array}$ & Test & Speaking test \\
\hline $\begin{array}{l}\text { 4. Identifying students and lecturers' perceptions of } \\
\text { teaching materials. }\end{array}$ & Interview & Interview guidelines \\
\hline
\end{tabular}

Questionnaire data were analyzed and described as well as objectively. The measurement scale used is the type of rating scale: 1 = not very good / not suitable, $2=$ not suitable, $3=$ sufficient, $4=$ good, and $5=$ very good / appropriate (Sugiyono, 2012).

\section{FINDING AND DISCUSSION}

In this section the findings obtained from the stage of development research, namely: (1) need analysis, (2) literature study (3) development of speaking teaching materials, (4) product validation (5) product revision, (6) product testing, (7) final products.

\subsection{Need analysis}

Needs analysis is a procedure that is applied in an effort to find out the needs of students. Richards (2002) states needs contain meaning wants, desires, demands, 
expectations, motivation, lacks, constraints, requirements. In identifying student needs, the study distributed questionnaires to students with the following results:

Table 2. Student Needs

\begin{tabular}{ll}
\hline No & Student expectations and needs \\
\hline 1 & Desired learning activities \\
\hline 2 & Desired speaking component \\
\hline 3 & Desired Topic \\
\hline 4 & Desired basic grammar \\
\hline 5 & Evaluation in speaking test \\
\hline
\end{tabular}

Table 2 showed that, student needs is very important not only for the needs of teaching materials but determines the expected future of learning. All of them will answer questions such as: how to learn good English, what are the expectations of students towards learning English, even how the future of learning English is learned. Analysis of needs in learning English is important to do in relation to the needs of English learners for a particular purpose.

Researchers also conducted interviews and distributed questionnaires to English lecturers to know their needs in teaching speaking:

Table 3. Lecturer Needs

\begin{tabular}{ll}
\hline No & Lecturers expectations and needs \\
\hline 1 & $\begin{array}{l}\text { The importance of teaching materials } \\
\text { for students to speak }\end{array}$ \\
\hline 2 & Systematics of teaching materials \\
\hline 3 & Form of presentation of material \\
\hline 4 & Learning Activities \\
\hline 5 & Learning methods \\
\hline 6 & Evaluation/assignment/exercise \\
\hline 7 & Problem in teaching speaking
\end{tabular}

\subsection{Literature study}

Literature study is done by analyzing books that have been taught by English lecturers in the Primary School Teacher Education study program. The aspects analyzed (1) the appropriateness of the contents of the material, (2) the use of language, (3) presentation, and (4) graphics. First, the topic and content of the speaking material have not adjusted to the needs of primary English teacher candidates. Second, the use of language is still difficult to understand. Third, the presentation of the material requires the practice of conversation in each of their interests and imagination when studying. Fourth, additional examples of speaking practice through pictures, tables and so on are needed to add completeness in graphic aspects.

\subsection{Development of speaking teaching materials}

Based on the results of the syllabus analysis, 12 topics were chosen to be developed in the production of speaking teaching materials. These topics include:

Table 4

Topics for speaking teaching material based contextual

\begin{tabular}{c|l} 
Lesson & \multicolumn{1}{c}{ Topic } \\
\hline 1 & Greeting and introducing \\
\hline 2 & Counting numbers \\
\hline 3 & Talking about family \\
\hline 4 & Describing object \\
\hline 5 & Talking about house \\
\hline 6 & School and class environment \\
\hline 7 & $\begin{array}{l}\text { Telling time and talking about daily } \\
\text { activity }\end{array}$ \\
\hline 8 & $\begin{array}{l}\text { Talking about feeling and health } \\
\text { issues }\end{array}$ \\
\hline 9 & Shopping time \\
\hline 10 & Asking and giving direction \\
\hline 11 & Talking about plans \\
\hline 12 & Telling past experience \\
\hline
\end{tabular}

The teaching material produced is in the form of speaking textbooks. Speaking teaching material developed by researchers consists of 3 parts, namely (1) the introduction, (2) the content, and (3) the concluding section. The textbook design of the speaking skills 
development can be seen in the following figure:

Figure 2

The textbook design of the Speaking Skills Development

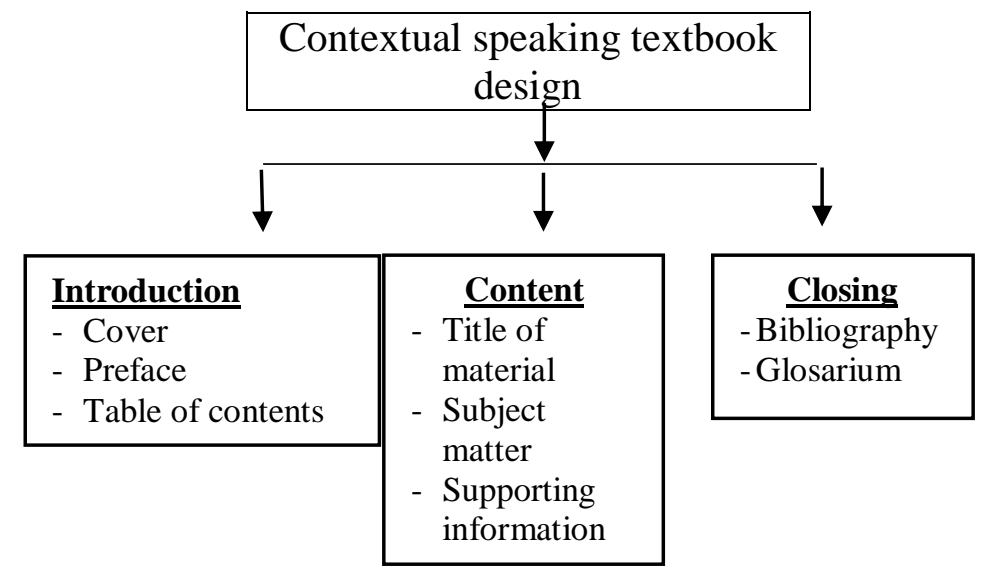

After designing teaching materials, it is continued by conceptualizing the contents of the material which is related to the contextual approach according to the needs of primary
English teacher candidates. Here is the concept of one of the contents of contextual teaching material based on speaking material:

Table 4. The Concept of the Contents of One of the MaterialiIn Contextual Speaking Teaching Materials

\begin{tabular}{|c|c|c|}
\hline Topic & Speaking activity & Contextual approach \\
\hline \multirow{10}{*}{$\begin{array}{l}\text { Topic } 1 \\
\text { Greeting and } \\
\text { Introducing }\end{array}$} & Pre speaking & \multirow[b]{2}{*}{ Constructivism } \\
\hline & 1. Focus learners' attention on speaking. & \\
\hline & 2. Provide input and/or guide planning. & Inquiry \\
\hline & Whilst speaking & \multirow[b]{2}{*}{ Questioning } \\
\hline & 3. Conduct speaking tasks. & \\
\hline & 4. Focus on language/skills/strategies. & \multirow[t]{2}{*}{ Learning community } \\
\hline & 5. Repeat speaking tasks. & \\
\hline & Post speaking & \multirow{3}{*}{$\begin{array}{l}\text { Authentic assessment } \\
\text { Reflection }\end{array}$} \\
\hline & 6. Direct learners' reflection on learning. & \\
\hline & 7. Facilitate feedback on learning. & \\
\hline
\end{tabular}

\subsection{Product validation}

The product must pass the validation stage (expert testing) first by using the instruments that have been made before it tests. The validation test of teaching materials includes 4 components, namely: 1) the feasibility of the contents of the material,
2) the language, 3) the presentation, and 4) graphics. The aim is to find out whether the teaching material meets the criteria or not. The design validation involved in this research was the teaching material expert and the English speaking material expert. Based on the results of expert judgment, an evaluation related to (1) improvement in the 
format of lesson plan, (2) addition of parts in teaching materials related to rational development, and (4) addition of illustrations/documentation. Syllabus and lesson plan consulted on expert judgment have been considered good or in accordance with the curriculum. A suggestion or comment on the assessment of this graphic component was by adding pictures or illustrations that interest students to learn teaching material that is developed.

\subsection{Product revision}

After validating product from expert, product must be revised by researcher. The revision phase will be completed after the product being developed is said to be feasible and can be tested.

\subsection{Product testing}

Contextual-based speaking teaching materials that have been validated by a team of experts are then followed up with a limited testing. The sample used was 20 students of primary school teacher education. This sampling technique used purposive sampling technique, in accordance with the purpose of sampling in the study. The students were given a questionnaire sheet to know the responses and evaluate the students in teaching material used.

\subsection{Final product}

After validating and testing product, the last stage is final product. This stage aims to improve the weaknesses of the product design that has been made. This revision is done by giving criticism and suggestions through an assessment instrument.

\section{CONCLUSION}

Based on the results of the discussion above, there are three conclusions. First, the need for speaking teaching materials needs to pay attention to a) learning topics adapted to the needs of primary English teachers' candidates, b) exercises and assignments in each material should be easily understood, and c) teaching materials ready to use in accordance with the conditions of the university. Secondly, developing prototypes into speaking teaching materials at the Muhammadiyah University of Tangerang. 12 chapters of speaking teaching material was chosen for Primary English teachers' candidates based on contextual approach. Third, the results of the effectiveness test show that speaking teaching materials are stated to be good. Through the findings of this study, several pedagogical implications can be made for the development of designs and materials for primary English teachers' candidates. By conducting needs analysis, lecturers can find out the needs and interests of students to make relevant teaching materials. These findings call for lecturers to apply the teaching material developed in the learning process as a main reference or as a supplementary material so that it can make learning material more interesting, innovative, and effective.

\section{REFERENCES}

Andi Tenri Ampa, M. B. D. A. A. A. (2013). The Development of Contextual Learning Materials for the English Speaking Skills. International Journal of Education and Research, 1(9), 1-10.

Bahrani, T. (2012). How to Teach Speaking Skill? Journal of Education and Practice, 3(2), 25-29. https://doi.org/10.1093/eltj/cci025.

Brown, James Dean. 1995. The Elements of a Language Curriculum: A Systematic Approach to Program Development.

H Ellington \& Race, P. (1993). Producing Teaching Materials. London: Kogan Page.

Johnson, Elaine B. (2002). Contextual Teaching and Learning. California: 
Corwin Press

Majid, Abdul. (2011). Perencanaan Pembelajaran Mengembangkan Standar Kompetensi Guru. Bandung: Rosdakarya.

Quinn, S. (2014). Problems and Difficulties of Speaking That Encounter English Language Students at Al Quds Open University. International Journal of Humanities and Social Science Invention, 5(12), 96-101.

Richard, Jack C. (2002). Curriculum Development in Language Teaching. NewYork: Cambridge University Press

Sad, S. N. (2008). Using Mobile Phone Technology in EFL Classes. English Teaching Forum, (4), 34-40.

Spratt, dkk. (2005). The TKT Teaching Knowledge Test Course. NewYork:
Cambridge University Press.

Tim Universitas Muhammadiyah Tangerang. 2015. Pedoman Akademik Universitas Muhammadiyah Tangerang Tahun Akademik 2015-2016. Tangerang: UMT Press.

Tomlison, Brian. (2003). Developing Materials for Language Teaching. London Continum

Walter R Borg dan Meredith D gall. (2003). Educational Research: An Introduction $7^{\text {th }}$ Edition, New York: Pearson Education.

Wang, Z. (2014). Developing accuracy and fluency in spoken English of Chinese EFL learners. English Language Teaching, $\quad 7(2), \quad 110-118$. https://doi.org/10.5539/elt.v7n2p110 